\title{
ANALISIS PARTISIPATIF TERHADAP \\ SISTEM KEPEMILIKAN TANAH DAN PROSES PEMISKINAN \\ DI DESA ROWOSARI JEMBER MELALUI SISTEM PEMETAAN GEOSPASIAL DAN SOSIAL
}

\author{
Muhammad Ardiansyah \\ Fakultas Dakwah IAIN Jember \\ ardonkuye@yahoo.com \\ Moh. Salman Hamdani \\ Fakultas Usuludin Adab dan Humaniora IAIN Jember \\ Salmanhamdani19@gmail.com \\ Nukman Hakim \\ Alumnus Insist Yogyakarta \\ hakim.siyb@gmail.com \\ Khairuddin \\ pascasarjana IAIN Jember \\ khairuddin82@gmail.com
}

\begin{abstract}
Rowosari has a beautiful landscape and natural layout. In the north, east and south, a row of circular pine hills forms a horseshoe. On the east side, back to the pine hill is Raung Mountain, which is almost always covered of clouds, rises to an altitude of 3,344 masl which makes it become the second highest mountain in East Java after Semeru Mount. The volcano located in the Ijen mountain complex area stuck its feet in three districts of Besuki, Jember, Bondowoso and Banyuwangi. However, at one settlement point, namely the Karang tengah village, which is part of the Barat Sawah village, residential settlements are concentrated in area of 1,728 hectares. The location of these settlements go north from the village road, surrounded by stretches of fields and small rivers. There are two entrances to this settlement, west and east. There are 56 heads of families living here with 51 houses. Houses are lined up and stretched, following the taneyan lanjhang-pattern which consists of a collection of houses inhabited by several families. Between settlements and fields restricted with rivers
\end{abstract}


and plants. The contrasting picture between the abundance of natural resources and the social conditions of the Rowosari community raises the general question of this study: why does the agriculture area and the wealth of natural resources not correlate with the population welfare? What happens in the relationship between humans and their homeland? Because the analysis of production relations in the agricultural sector is the backbone of the socio-economic structure of rural society, the analysis is the main theme in this study. What happened in the village, especially in the West field of Rowosari Village, actually it can be solved, for example by institutionalizing savings and loans cooperatives, processing agriculture by using organic farming systems, and developing village tourism by utilizing village potential. Nature tourism: panoramic views of mountains, waterfalls, panoramic views of fields and rivers flowing with clear water, become the main attraction to be developed as a village tour. Livestock and fisheries can also be developed because there are abundant river and green food sources. Village funds can be used for that. The priority of village development should be based on analyzing data from participatory mapping, not by a handful of village government elites. Priority of the programs should be directed by building food security, creating jobs towards village economic sovereignty. actually the land in the forested area could be managed by the community. However, the land management rights given to Chinese ethnic who managed it for cash crops such as sengon and coffee. Village people only become wage laborers to care for, to fertilize and to harvest the results. because of the difficult terrain to reach the location, the villagers were finally reluctant to manage the land with little wage and erratic work. They are forced to look for work outside the village. There must be good faith and political decisions by the village government, for example by making regulations regarding the prohibition of selling agricultural land to people outside the village, so that the land does not turn into housing or become an asset for investment which certainly has no commitment to agricultural development. In addition, villages must develop BUMDES as an economic effort by opening jobs to improve the community welfare, especially for those who do not have job and agricultural land. Management of zakat, infaq, shodaqoh from rich people, if managed properly, can become business capital or help alleviate for those who really need, this could prevent villagers from mi- 
grating to the city. Because, if many villagers migrate to the city, when they return, they will bring the culture of the city that is not in line with the values and norms of the village.

\section{Kata Kunci : Kemiskinan, Kepemilikan Tanah}

\section{PENDAHULUAN}

Desa Rowosari berada di wilayah Kecamatan Sumberjambe Kabupaten Jember. Menurut ilmu bumi, Rowosari terletak pada $4^{\circ} 21^{\prime}-3^{\circ} 31^{\prime}$ Lintang Selatan dan $140^{\circ} 10^{\prime}-115^{\circ} 40^{\prime}$ Bujur Timur. Di sisi barat berbatasan dengan desa Sumberjambe. Di sisi utara, berbatasan dengan desa Jambearum. Di sisi selatan berbatasan dengan desa Gunungmalang dan di sisi timur berbatasan dengan kawasan hutan di kaki gunung Raung. Dari ibukota kabupaten ke desa berjarak 39, 3 kilometer dengan waktu tempuh satu setengah hingga dua jam arah timur laut. Tak ada alat transportasi umum ke desa ini. Rowosari memiliki luas wilayah $6,53 \mathrm{~km}^{2}$ dan terdiri dari 6 dusun, $12 \mathrm{ru}-$ kun warga (RW) dan 29 rukun tetangga (RT). Enam dusun itu adalah Gardu Utara, Gardu Tengah, Gardu Timur, Pringpaddu, Lumbung dan Barat Sawah dengan jumlah penduduk, berdasarkan Statistik Daerah Kecamatan Sumberjambe Tahun $2015{ }^{1}$ terdiri dari 2391 kepala keluarga. Jika luas wilayah desa dibagi dengan jumlah penduduk, maka tingkat kepadatan penduduk di Rowosari 757,48jiwa/ $/ \mathrm{km}^{2}$. Mengacu pada Undang-undang Nomor: 56/PRP/1960, maka tingkat kepadatan penduduk di Rowosari termasuk dalam kategori sangat padat (lebih dari 401 jiwa $/ \mathrm{km}^{2}$ ).

Di perbukitan di sebelah timur, di kaki gunung Raung, tujuh air terjun memancarkan airnya sepanjang tahun membentuk beberapa aliran sungai yang membelah-melintang desa. Persawahan terhampar hijau. Pohonpohon kelapa dan pohon jambe menjulang tinggi di antara pematang. Gubuk-gubuk berdiri di sudut-sudut pematang sawah, menjadi tempat para petani melepas lelah dan berlindung dari sengatan matahari. Sungai dengan airnya yang dingin nan jernih menjadi tempat berendam yang menyegarkan, menghapus biang keringat dan kutu-kutu sawah yang menempel di badan. Di desa ini, orang bisa menanam padi sepanjang musim. Air sungai selalu mengalir dan sanggup mengairi areal persawahan. Orang-orang desa tak perlu membuat sumur untuk pasokan air di dapur. Pipa-pipa mengalirkan 
air ke rumah-rumah warga, dari mata air yang berada di kaki gunung. Airnya begitu jernih, hingga banyak rumah tangga meminumnya tanpa perlu memasaknya terlebih dulu. Namun, kekayaan alam ini tidak paralel engan kondisi sosial ekonomi masyarakatnya. Desa ini tampak kusam dan sesak. Rumah-rumah tak memiliki pekarangan yang luas. Permukiman penduduk terserak di beberapa titik, di sepanjang garis lurus maupun lengkung, atau menyerupai bercak. Di sepanjang jalan desa, sejak dari gapura pintu masuk, banyak dijumpai rumah yang dibuat dari papan kayu. Agaknya, rumahrumah dibangun ala kadarnya, hampir tanpa sentuhan desain dan konsep tata ruang yang memadai. Banyak rumah terbuat dari papan kayu atau anyaman bambu (gedek).

Tak sedikit dinding papan kayu dan gedek yang mulai keropos dan melapuk. Bahan rumah memang bukan dari kayu jati sebagaimana banyak dijumpai di wilayah perbatasan Jawa Timur dan Jawa Tengah yang kuat dan berumur panjang. Cat-cat rumah mulai mengelupas, warnanya memudar.

Di satu titik permukiman, yakni kampung Karangtengah, yang menjadi bagian dari dusun Barat Sawah, permukiman warga terkonsentrasi di lahan seluas 1, 728 hektar. Letak permukiman ini menjorok masuk ke arah utara dari jalan desa, dikitari hamparan persawahan dan sungai kecil. Ada dua jalan masuk ke permukiman ini, sebelah barat dan timur. Ada 56 kepala keluarga tinggal di $\operatorname{sini}^{1}$ dengan lima puluh satu rumah. Rumah-rumah berjajar-berhimpit dan memanjang, mengikuti pola taneyan lanjhang -pola permukiman yang terdiri dari kumpulan rumah yang dihuni oleh beberapa keluarga yang memiliki ikatan kekeluargaan satu sama lain. Antara permukiman dan lahan persawahan dibatasi sungai dan tanaman hidup. Rata-rata rumah di Karangtengah (RT 5) berukuran 6xl2 meter yang dibagi menjadi ruang tamu (bagian depan), ruang keluarga sekaligus kamar tidur (bagian tengah), dan dapur (bagian belakang).

Dalam satu rumah ada yang terdiri dari dua hingga tiga kepala keluarga. Di beberapa rumah, tidak ada kamar tidur khusus untuk masing-masing pasangan keluarga -hanya berupa dipan yang atasnya ditutup kelambu. Jarak antar dipan hanya dua meter. Tentu saja, privasi masing-masing pasangan

\footnotetext{
${ }^{1}$ Ada sejumlah orang yang mengaku sebagai buruh tani yang mempunyai tanah, namun luasnya kurang dari 500 meter persegi.
} 
suami istri kurang terjaga. Sebagian rumah diKarangtengah berdinding gedhek (anyaman bambu). Sebagian kecil saja yang berdinding tembok. Lainnya berupa papan kayu. Lantai rumah sebagian besar berupa plester, banyak rumah bahkan masih berlantai tanah. Sebagian besar rumah tak memiliki halaman yang lebar. Halaman depan rumah sekaligus berfungsi sebagai jalan yang menghubungkan satu rumah dengan rumah lainnya, atau satu blok rumah dengan blok rumah lainnya.

Limbah kotoran ternak sapi dan kambing menumpuk di tepian bantaran sungai kecil di belakang rumah yang sekaligus juga digunakan untuk buang air besar, mandi, mencuci pakaian dan alat-alat dapur. Sampahsampah plastik bekas bungkus makanan ringan, detergen, dan lain-lain tampak berserakan dan menumpuk menjadi gundukan-gundukan di sekitaran permukiman warga. Tiga bangunan MCK umum yang dibangun dari dana PNPM hanya digunakan untuk mandi bagi sebagian warga, selebihnya memilih mandi di sungai yang airnya tercemar kotoran dan limbah rumah tangga. Kakus tidak difungsikan, bahkan ditutup menggunakan papan kayu. Semua warga buang air besar di sungai kecil yang mengelilingi permukiman.

Kondisi ini menjadi ironis mengingat, dalam perspektif sejarah desa, Rowosari dibabat oleh seorang yang berasal dari Madura: Bujuk Marliya. ${ }^{3}$ SejarahDesa Rowosari bermula dari kedatangan Bujuk Marliya yang berasal dari Lamparan, Sampang, Madura ke kawasan hutan dan rawa-rawa di bawah kaki gunung Raung, yang kini menjadi bagian dari wilayah Desa Rowosari, sekitar pertengahan abad ke-19. Masyarakat Rowosari adalah pewaris tanah air dan kekayaan sumber daya alam di kaki Gunung Raung. Namun, mereka kini justru menjadi penumpang di desanya sendiri.

\section{FOKUS MASALAH}

Gambaran kontras antara melimpahnya sumber daya alam dan kondisi sosial masyarakat Rowosari tersebut menerbitkan pertanyaan umum penelitian ini: kenapa luasnya lahan pertanian dan kekayaan sumber daya alam tidak berkorelasidengan kesejahteraan penduduknya? Apa yang terjadi dalam hubungan antara manusia dan tanah airnya? Karena analisis hubunganhubungan produksi di sektor pertanian merupakan tulang punggung struk- 
tur sosial ekonomi masyarakat desa, maka analisa tersebut menjadi tema utama dalam penelitian ini."

Pertanyaan di atas memunculkan pertanyaan lebih lanjut tentang sistem kepemilikan dan pola pengusahaan tanah pertanian di Rowosari, khususnya di dusun Barat Sawah yang menjadi pokok soal pertama dalam penelitian ini.

Di kalangan masyarakat Madura, leluhur dan nenek moyang disebut bujuk. Di hampir tiap-tiap komunitas Madura, kita bisa menemukan makam para bujuk ini. Tidak hanya dipercaya sebagai "pembabat desa", bujuk juga diyakini sebagai tokoh penyebar agama Islam sehingga tidak jarang kuburannya banyak diziarahi. Menurut cerita lisan, sebelum mbabat alas, Bujuk Marliya melakukan ritual puasa selama empat puluh hari. Bujuk Marliya dikenal sebagai orang sakti, bahkan macan pun takut padanya. Istrinya, konon, adalah seorang bidadari. Makamnya terletak di pingir hutan pinus di Dusun Barat Sawah yang berbatasan dengan Desa Gunungmalang.

Tiap tahun, pada bulan Suro (Muharram), anak cucu Bujuk Marliya berkumpul di area makam membaca tahlil bersama dan pembacaan riwayat singkat sang Bujuk, setelah sehari sebelumnya diadakan semaan Al-Qur'an. Semua warga yang datang membawa berkat untuk saling ditukarkan dengan warga yang lain. Makam Bujuk Marliya hingga kini masih banyak diziarahi oleh orang-orang tidak hanya dari Rowosari sendiri, tetapi dari berbagai desa sekitar bahkan dari luar Jember. Khusus setiap malam Jum'at legi, warga sekitar mengadakan khataman Al-Qur'an dan tahlil bersama di areal makam Bujuk Marliya. Catatan silsilah Bujuk Marliya dan keturunannya tersimpan salah satunya di rumah Kyai Burhan, salah satu tokoh masyarakat di Dusun Barat Sawah. Kyai Burhan sendiri merupakan keturunan ketujuh. Catatan tersebut ditulis dengan huruf Arab dalam bahasa Madura.

Bagaimana sistem kepemilikan tanah di Rowosari? Kenapa ada pemusatan kepemilikan tanah pertanian hanya di segilintir orang? Bagaimana proses kepemilikan tanah-tanah pertanian dan apa akibatnya?

\section{PEMBAHASAN}

${ }^{2}$ Hiroyoshi Kano, Pagelaran: Anatomi Sosial Ekonomi Pelapisan Masyarakat Tani Di Sebuah Desa Jawa Timur (Yogyakarta: Gadjah Mada University Press, 1990), hal. ix. 


\section{Transformasi Perdesaan: Sketsa Teoritik}

Mengenai kemiskinan masyarakat di desa-desa di Jawa -hubungan manusia dan tanahnya dalam tata-kehidupan ekonomi di perdesaan, dua pandangan mengemuka:pertama pandangan tentang kemiskinan rakyat petani di Jawa yang meminimalisir kecenderungan diferensiasi lapisan di kalangan masyarakat petani, namun sebagai akibat dari semakin padatnya penduduk, menciutnya lahan pertanian dan kuatnya tolong-menolong dan jiwa kegotongroyongan di kalangan masyarakat perdesaan. Kondisi ini tidak serta merta menimbulkan diferensiasi lapisan di dalam masyarakat petani, terutama akibat kuatnya kelembagaan tolong-menolong di masyarakat desa. Situasi inilah apa yang disebut Clifford Geertz sebagai "pemerataan kemiskinan” (shared poverty). ${ }^{3}$

Pandangan sebaliknya mengemukakan bahwa di masyarakat perdesaan sudah terjadi diferensiasi yang cukup tajam akibat semakin melebarnya perbedaan luas kepemilikan lahan. ${ }^{4}$ Kemiskinan di perdesaan diakibatkan terutama oleh ketimpangan kepemilikan lahan ini. Bahkan, konflik-konflik agraria di Jawa yang berciri agraris kerap dipicu oleh penguasaan dan pemusatan kepemilikan lahan. Beberapa riset membuktikan tesis ini, di antaranya yang dilakukan oleh Henrik ten Dam, William L. Colier dan Sajogyo. ${ }^{5}$

'Namun demikian, rupanya masih banyak kekurangan pada pengkritikan itu, antara lain kurang banyaknya dan kurang telitinya data penelitian yang telah terkumpul sehingga belum dapat dikatakan sudah diberikan ja-

${ }^{3}$ Pandangan ini dikemukakan dengan baik oleh Clifford Geertz dalam bukunya Involusi Pertanian: Proses Perubahan ekologi Di Indonesia, terjemahan S. Supomo, (Jakarta: Bhratara Karya Aksara, 1976)

${ }^{4}$ Hiroyoshi Kano, Pagelaran: Anatomi Sosial Ekonomi Pelapisan Masyarakat Tani Di Sebuah Desa Jawa Timur, hal. viii.

${ }^{5}$ Henrik ten Dam, "Coëperen vanuit het gezichtspun der desastruktuur in Tjibodas", Indonesie, Th. 9, 1956, hlm. 89-116. Margo L. Lyon, Bases of Cinflict in Rural Java, Research Monograph Series No. 3, Center for South and Southeast Asia Studies, University of California, 1970. William L. Colier, Agricultural Evolution in Java: The Decline of Shared Poverty and Involution, Bogor, n.d. (c 1977). Sajogyo, "Pertanian, landasan tolak bagi pengembangan bangsa Indonesia", kata pengantar dalam buku terjemahan karya C. Geeertz, Involusi Pertanian, Proses Perubahan Ekologi di Indonesia, Jakarta, 1976. Dikutip dalam Hiroyoshi Kano, Pagelaran: Anatomi Sosial Ekonomi Pelapisan Masyarakat Tani Di Sebuah Desa Jawa Timur, hal. viii. 
waban yang tegas kepada persoalan tersebut." ${ }^{\text {M }}$ Menurut Kano, uraian terhadap sejarah diferensiasi sosial terkait luas kepemilikan dan penguasaan tanah secara terperinci akan membantu kita memperoleh jawaban kemiskinan di kalangan petani di perdesaan. Hiroyoshi Kano melalui penelitiannya di sebuah desa di Malang Selatan mempertegas posisi para penentang teori shared poverty Clifford Geertz dengan memperkaya sekaligus mempertajam analisis data. ${ }^{7}$

Baik teori shared poverty maupun diferensiasi sosial terkait kepemilikan tanah dan kemiskinan di desa, keduanya tidak perlu diperhadapkan secara diametral. Penguasaan alat-alat produksi, terutama dalam hal ini tanah, dengan sendirinya mengarah ke akumulasi kapital. Diferensiasi ekonomi akibat pemusatan penguasaan alat-alat produksi di desa menciptakan ruang bagi proses pemiskinan di kalangan masyarakat desa. Namun demikian, budaya tolong menolong dan gotong royong -yang bukan lahir sebagai suprasutruktur dari ekosistem pertanian sebagaimana dikemukakan Geertz- juga menjadi semacam "jaminan sosial' bagi kelangsungan hidup masyarakat desa. Sistem "kedokan" dalam pengusahaan pertanian di Jawa, misalnya, tidak semata bisa dibaca sebagai hubungan ekonomi antara tuan tanah dan buruh, tapi juga spirit berbagi ruang kue ekonomi.

Kemiskinan di perdesaan Jawa, menurut Boeke, ${ }^{8}$ diakibatkan oleh mentalitet orang-orang desa yang yang tidak memiliki karakter homo economicus sebagaimana menjadi ciri masyarakat kapitalis di Barat. Kegagalan politik etis pemerintah kolonial Belanda diakibatkan oleh ketidakmampuannya melihat ciri dualistik ekonomi Hindia Belanda: antara sistem ekonomi komunalistik Timur dan sistem ekonomi kapitalistik Barat. Dua sistem ekonomi ini digerakkan oleh logika internal masing-masing, dan sedikit saja bersinggunggan satu sama lain. Dan, anehnya, dua sistem ekonomi ini berjalan bersamaan dalam roda kehidupan sosial ekonomi di perdesaan.

Terlepas dari berbagai kritik yang dilancarkan terhadap model dualisme ekonomi Boeke, ${ }^{9}$ teori ini membantu menggambarkan tumpang tindih dan

\footnotetext{
${ }^{6}$ Hiroyoshi Kano, Pagelaran: Anatomi Sosial Ekonomi Pelapisan Masyarakat Tani Di Sebuah Desa Jawa Timur, hal. viii.

${ }^{7}$ Hiroyoshi Kano, Ibid.

${ }^{8}$ J.H. Boeke, Prakapitalisme di Asia, terj. D. Projosiswoyo, Jakarta: Sinar Harapan, 1983.

${ }^{9}$ Tania Murray Li, The Will to Improve, Perencanaan, kekuasaan dan Pembangunan di
} 
saling silang kehidupan sosial ekonomi di perdesaan, bagaimana akumulasi modal melalui penguasaan alat-alat produksi (khususnya tanah) yang kemudian menciptakan diferensiasi sosial di kalangan masyarakat petani di perdesaan bersinggungan dengan karakter komunal masyarakat perdesaan. Karakter komunal dan tradisional masyarakat desa membuatnya tidak beranjak dari kemiskinan. Untuk keluar dari kemiskinan, menurut Boeke, masyarakat desa harus kembali ke pola desa lama dan menjauhkan diri dari ekonomi jual beli. "Kehidupan desa harus ditata ulang", kata Boeke, dan yang terpenting adalah "meyakinkan bahwa masyarakat desa agar puas dengan nilai-nilai spiritual yang akan memungkinkan mereka merasa cukup di dalam kehidupan yang mereka hadapi.”10

Namun, saran Boeke agar mengembalikan "watak asli masyarakat Timur" dan mengembalikan kehidupan desa ke dalam keseimbangan dan harmonis merupakan proyek yang sangat sulit -untuk tidak mengatakan hampir mustahil. Hal ini dikarenakan masyarakat desa bukanlah masyarakat yang tertutup. Melalui proyek pembangunan infrastruktur yang menjadi prioritas program pembangunan pemerintah saat ini, maka penetrasi kota (modal) ke desa kian gencar, interaksi desa dengan kota dan masyarakat yang lebih luas semakin intensif. Maka, "cakrawala desa harus diperluas, sekali kita menerima perkembangan spesialiasi, jual beli, dan perluasan pasar. Desa tidak bisa kembali ke pola tradisionalnya, pola memenuhi sendiri kebutuhannya, tetapi harus jadi bagian dari sistem pasar yang lebih luas."11

Maka, kemiskinan di desa tidak bisa dilihat dari segi penguasaan tanah semata, melainkan harus juga mempertimbangkan kegiatan-kegiatan ekonomi non agraris, baik dengan kekuatan negara dalam konteks pemerintahan juga dengan aneka pekerjaan non pertanian. Dalam hal ini harus dilihat bagaimana dampak pembangunan yang didorong oleh kebijakan-kebijakan pemerintah terhadap perekonomian desa dengan memusatkan perhatian terhadap kesempatan kerja di luar bidang pertanian. ${ }^{12}$

Indonesia, terj. Hery Santoso dan Pujo Semedi, Tangerang Selatan: Marjin Kiri, 2012, h. 89.

${ }^{10}$ Wertheim, hal. 42, dikutip dalam Tania Murray Li, The Will to Improve, Perencanaan, kekuasaan dan Pembangunan di Indonesia, hal. 89.

${ }^{11}$ Sajogyo (Peny.), Bunga Rampai Perekonomian Desa, Bogor: Yayasan Obor, 1982, hal. 59.

${ }^{12}$ Hiroyoshi Kano, Pagelaran, Anatomi Sosial Ekonomi Pelapisan Masyarakat Tandi Di 
Dengan memetakan dan menganalisa sistem penguasaan lahan pertanian di desa, ketersediaan kesempatan kerja di luar pertanian, maka tahap analisis berikutnya adalah membaca gerak sosial petani dan kaum buruh tani di desa: bagaimana masa depan mereka. Sebagaimana pertanyaan Kano di penutup bukunya: "Apakah mereka akan terpaksa meninggalkan desa supaya pindah ke kota sebagai akibat dari rasionalisasi dan mekanisasi pertanian yang mungkin terjadi di masa datang ataukah mereka dapat memulai kehidupan baru dengan penuh harapan sambil mendapat pekerjaan di bidang industri baru tercipta? Apakah mereka dapat mempunyai perwakilan politik tersendiri yang dapat menyalurkan aspirasi mereka di masa depan?"13

\section{PENDEKATAN DAN METODE PENELITIAN}

Kajian mengenai kepemilikan tanah di Rowosari Jember akan didekati dengan pendekatan partisipatif. Dalam perspektif teori ini, peneliti terlibat langsung dalam kehidupan masyarakat yang berorientasi pada manusia karena meletakkan masyarakat sebagai subyek dalam pembangunan dengan menekankan partisipasinya pada segala aspek.

Partisipasi masyarakat dalam proses pembangunan memang mutlak diperlukan dan hampir tidak ada yang menyangkal terhadap pentingnya partisipasi masyarakat dalam pembangunan karena pada akhirnya masyarakatlah yang akan menikmati hasil pembangunan tersebut. Namun dalam perjalanannya, partisipasi yang dipandang mutlak harus ada dalam pembangunan dipahami secara berbeda-beda, bahkan ada yang mengartikan partisipasi secara salah kaprah.

Pendekatan kritis-partisipatif dan pemberdayaan menjadi terminologi kunci dalam penelitian ini. Metode yang dipilih adalah metode participatory action research yang menggabungkan dua perspektif: ilmu dan praktik. ${ }^{14} \mathrm{Me}$ tode ini dipilih karena menuntut partisipasi masyarakat sebagai subjek dalam penelitian ini, juga terutama mengajak masyarakat melakukan analisa kritis terhadap upaya penemuan sumber masalah kemiskinan dan kesenjangan

\footnotetext{
Sebuah Desa Jawa Timur, hal. ix.

${ }^{13}$ Hiroyoshi Kano, Ibid.,

${ }^{14}$ Jang Bergold dan Stefan Thomas, "Participatory Research Methods: A Methodological Approach in Motion", dalam jurnal Forum: Qualitative Social Rearch, Vol 13 No 1 (2012), hal. 1.
} 
sosial di desa.

Dengan menggunakan pendekatan PAR, penelitian ini tidak dalam posisi "bebas nilai" atau tidak memihak, sebagaimana pendekatan penelitian lainnya yang menuntut obyektivitas. Sebaliknya, pemihakan dalam penelitian ini jelas: mereka yang dilemahkan, dimiskinkan. Karena itu, penelitian ini tidak berhenti di laporan hasil penelitian dan rekomendasi untuk penelitian lebih lanjut, tetapi berorientasi pada transformasi sosial: peningkatan pengetahuan dan kapasitas masyarakat yang dimiskinkan untuk memahami dan megubah situasi mereka menjadi lebih baik.

Langkah-langkah penelitian dimulai dari pengkajian desa secara partisipatif bersama masyarakat untuk memperoleh informasi dan data dengan teknik pemetaan geo-spasial dan sosial desa. Melalui strategi ini akan didapatkan gambaran mengenai tata guna lahan, kondisi permukiman, sanitasi dan air bersih, serta kondisi ekonomi dan sosial masyarakat. Informasi dan data yang terpenting adalah luas lahan pertanian dan kepemilikan lahan. Dengan ini diperoleh gambaran mengenai potensi hasil pertanian dalam rangka memenuhi kebutuhan pangan masyarakat, juga terutama diferensiasi yang terjadi dalam konteks kepemilikan lahan.

Teknik pengumpulan dan analisis data, diguakan metode berbagi cerita (sharing), wawancara mendalam (in-depth interview) dan diskusi kelompok terfokus (focus group discussion/FGD). Guna memperdalam data dan mempertajam analisis, teknik-teknik pemetaan gagasan (mind mapping), diagram pohon masalah (problem tree), grafik kecenderungan (trend lines), skala prioritas masalah (ranking matrix). Semuanya dilakukan secara partisipatif, dengan melibatkan sebanyak mungkin masyarakat desa.

Pembuatan peta geospasial sangat penting untuk mengetahui luas dan kondisi/tata guna lahan yang ada, status kepemilikan, dan lain sebagainya. Informasi ini dibutuhkan sebagai dasar analisis sumberdaya alam, pertanian, perkebunan dan sistem atau pola penguasaan lahan dalam kaitannya dengan kedaulatan pangan dan ketimpangan sosial yang terjadi akibat sistem penguasaan lahan. Untuk itu, hal yang pertama dilakukan dalam pemetaan adalah membuat peta geospasial dusun dengan memanfaatkan teknologi GPS (Global Positioning System) yang datanya nantinya diolah menggunakan sistem aplikasi Quantum GIS (Geographic Information System). 
GPS dalam hal ini difungsikan sebagai alat menggambar peta permukaan bumi secara digital dengan skala tertentu sekaligus menghitung luas lahan, sekaligus menentukan posisi lokasi yang dipetakan dalam peta rupa bumi secara global. Sistem pemetaan secara digital ini lebih memudahkan untuk updating data, tentunya ketika diintegrasikan dengan aplikasi QGIS. Yang terkahir adalah aplikasi software pengolah data spasial dan sosial, baik yang diperoleh dari GPS maupun data hasil survei rumah tangga (data sosial). Pilihan Q-Gis didasari oleh beberapa pertimbangan: kehandalan dan tampilan cukup baik, bersifat open source (tak berbayar) dan tidak memerlukan lisensi. Dibanding software pengolah data lain seperti ArcGIS dan ArcView, misalnya, QGIS memiliki fitur-fitur yang sama, seperti georeferencing, dijitasi, pembuatan peta tematik, perhitungan luasan, dan proses pengolahan data baik dalam bentuk raster maupun vektor.

\section{Pemetaan geospasial dan sosial dan Situasi Politik yang Kurang Men- guntungkan}

Mengingat keterbatasan waktu dan tenaga, pemetaan spasial dan sosial hanya dilakukan di Dusun Barat Sawah. Untuk tingkat desa, pemetaan spasial hanya dilakukan untuk mengetahui batas wilayah Desa Rowosari dengan melakukan penelusuran menggunakan GPS. Selain itu, ternyata banyak kendala yang dihadapi selama kegiatan pemetaan spasial dan sosial yang berpengaruh kepada proses pengumpulan dan analisis data.

Sosialisasi mengenai kegiatan pemetaan spasial dan sosial pertama kali dilakukan ke sejumlah warga di kampung Karangtengah Dusun Barat Sawah. Kedekatan kami dengan warga kampung Karangtengah sebenarnya sudah terbangun sejak beberapa tahun sebelumnya, karena pernah dua kali kami mengadakan kegiatan workshop-workshop participatory action research (PAR) bagi kalangan dosen IAIN Jember. Setelah memahami apa maksud dari kegiatan pemetaan spasial dan sosial, sesuai kesepakatan, kami dan beberapa warga memutuskan untuk menyampaikan menyosialisasikan kegiatan ini ke pemerintah desa.

Kami menemui Kepala Desa Rowosari, Wasi. Namun, karena kondisi Wasi yang mengalami sakit stroke, kami tidak bisa berbincang banyak untuk menyosialisasikan dan menjelaskan maksud kegiatan pemetaan. Meski de- 
mikian, Wasi menyetujui rencana kegiatan ini dan menyarankan untuk berkoordinasi dengan Busri, pejabata Kepala Urusan Pemerintahan Desa Rowosari yang memang ditugaskan sebagai sebagai kepala rumah tangga pemerintahan desa Rowosari mewakili Wasi.

Ketika kami menemui Busri, setelah kami menjelaskan apa, bagaimana, fungsi dan manfaat pemetaan ini, dia juga menyetujui dan siap mendampingi kegiatan ini sekaligus mengkoordinasikannya dengan perangkat desa yang lain. Namun, kenyataannya, Busri tidak cukup proaktif dan terkesan hanya menunggu. Belakangan, kami tahu bahwa koordinasi antar pejabat pemerintahan Desa Rowosari tidak berjalan dengan baik. Konflik akibat pilihan kades yang dimenangkan Wasi masih terasa. Munawir, sekretaris desa, ternyata merupakan tangan kanan dari kepala desa sebelumnya, Jamilah Supardi yang kalah dalam pencalonannya kembali untuk periode yang kedua kalinya. Antara Wasi, Busri dan kelompok Munawir dalam beberapa hal berseberangan sehingga banyak urusan pemerintahan desa menjadi terbengkalai. Kami sendiri tidak menemui Munawir, sekretaris desa, mengingat Wasi -kepala desa yang sah yang sedang memerintah walaupun dalam kondisi sakit- tidak menyarankan kami menemui dan berkoordinasi dengan Munawir.

Mempertimbangkan dukungan yang tidak maksimal dari perangkat desa, kami putuskan melakukan pemetaan skala dusun, yakni Dusun Barat Sawah. Harapannya, jika pemetaan di tingkat dusun ini berhasil dan sistem informasi dusun terbentuk dan dapat dijadikan sebagai basis data untuk analisa sosial ekonomi di tingkat dusun, kami akan menindaklanjutinya untuk tingkat desa. Dengan pengaruh Kyai Burhan, kepala dusun Barat Sawah, Haji Muzakki, menyetujui dan mendukung kegiatannya ini. Maka dibentuklah tim pemetaan dusun yang kebetulan seluruhnya merupakan warga kampung Karangtengah dan ketua-ketua RT di Dusun Barat Sawah.

Di kampung Karangtengah sendiri juga terbelah dua terkait aspirasi politik pilihan kepala desa. Sebagian besar warga di Karangtengah mendukung Wasi, sementara kelompok kecil Kyai Burhan, ketua BPD yang memiliki hubungan yang sangat dekat dengan Supardi, mantan kepala desa yang juga merupakan suami Jamilah, sebagai tokohnya, justru mengampanyekan Jamilah Supardi. Kedua kelompok tersebut masih satu kerabat, sebenarnya. 
Kemenangan Wasi dan, sebaliknya, kekalahan Jamilah agak merenggangkan hubungan kedua kelompok ini. Namun kami sebagai orang luar Rowosari yang memang sejak sebelum pilkades sudah menjalin hubungan baik dengan warga Karangtengah secara keseluruhan tidak bisa diterima oleh kedua belah pihak. Baik pihak Kyai Burhan maupun kelompok pendukung Wasi yang ditokohi Dhofir, ketua RT di Karangtengah, bisa duduk bersama mendiskusikan rencana pemetaan spasial dan sosial di Barat Sawah. Hubungan kekerabatan mencairkan mereka.

Setelah menjelaskan apa itu pemetaan dan fungsinya bagi perbaikan kehidupan masyarakat desa melalui program-program berbasis data sehingga tepat sasaran, disepakatilah untuk dilaksanakan. Konsekeunsinya, kegiatan ini harus dilakukan bersama-sama secara partisipatif. Perangkat apa saja, baik alat maupun ketrampilan, yang dibutuhkan untuk melaksanakan pemetaan sebisa mungkin dipenuhi bersama. Namun, untuk alat seperti GPS, komputer, kamera dan formulir pendataan sosial kami (tim dari IAIN Jember) yang menyediakan. Tim dari warga Karangtengah diperkenalkan dan mempraktikkan penggunaan GPS, QGIS dan simulasi pendataan sosial.

Setelah tahap sosialisasi, pembentukan tim, dan pelatihan penggunaan alat GPS dan Q GIS, tim menyepakati melakukan penelusuran desa untuk mengetahui batas wilayah desa sekaligus luas wilayahnya. Hari Minggu, sehari penuh, tim pemetaan berjalan menyusuri perkampungan, persawahan, dan hutan mengelilingi wilayah desa Rowosari. Secara swadaya, tim pemetaan membawa bekal makanan dan minuman untuk dimakan di perjalanan. Penelusuran dimulai dari jam enam pagi dan berakhir jam empat sore, menempuh jarak delapan belas kilometer naik turun bukit dan jurang. Dalam perjalanan, sering muncul perdebatan mengenai batas desa, atau ketika berhadapan dengan jalan yang terjal, apakah tidak sebaiknya menghindar dan melewati jalan yang aman. Namun perdebatan itu terselesaikan dengan kesepakatan bersama berdasarkan informasi yang paling kuat dari salah satu perangkat desa yang turut serta dalam penelusuran. Untuk medan jalan yang berat, tim pemetaan akhirnya memutuskan tetap harus melaluinya. Selesai penelusuran batas desa, tim melanjutkan penelusuran batas dusun dan jalanjalan dusun.

Setelah penelusuran selesai, data batas wilayah Desa Rowosari berfor- 
mat GPX di GPS dikonversi ke QGIS dengan cara memformat file ke SHP agar bisa diolah/diedit. Format data SHP ini kemudian diolah di QGIS guna mengetahui tata guna lahan: berapa luas lahan permukiman, lahan pertanian dan lahan milik perhutani. Dari sini kita bisa melihat apakah tata guna lahan di Rowosari sudah sesuai proporsi memenuhi prinsip keseimbangan. Keseimbangan ini penting untuk mengukur sejauh mana kelestarian ekosistem bisa dipertahankan dan berkelanjutan. Tugas olah data ini, karena tim dari Karangtengah belum begitu akrab dengan QGIS dan operasional komputer, untuk sementara dikerjakan oleh salah satu anggota tim, Nukman Hakim, orang yang paling menguasai QGIS di antara anggota tim. Namun demikian, hasil pengolahan data ini diperlihatkan kepada seluruh tim pemetaan untuk ditelaah dan dikoreksi bersama-sama. Setelah disepakati, berlanjut ke tahap berikutnya: pemasakan ID rumah, penitikan dan pemotretan.

Tahap selanjutnya adalah pemasangan ID rumah, penitikan dan pemotretan rumah secara serentak. Perangkat yang digunakan adalah stiker nomor rumah, GPS untuk penitikan rumah dan kamera untuk pemotretan. Kegiatan ini hanya dilakukan di Dusun Barat Sawah. Hasil kesepakatan, pemasangan ID rumah dimulai dari RT 5 Dusun Barat Sawah, alias dari kampung Karangtengah di mana Dhofir, anggota tim pemetaan, sebagai ketua RT-nya. Setelah selesai satu RT, berlanjut ke RT berikutnya, dan demikian seterusnya. Seluruh hasil penitikan dan pemotretan rumah diintegrasikan dengan data batas desa dan dusun dan tata guna lahan di QGIS. Banyak problem teknis muncul saat mengintegrasikan data di QGIS. Kesalahan penulisan nomor di GPS dan foto hasil pemotretan membuat data ID, titik rumah dan foto rumah tidak sinkron. Maka, setelah diintegrasikan dan ditampilkan di slide, semua anggota tim menelaah satu persatu guna mensinkronkan ketiga data tersebut. Pekerjaan ini makan waktu cukup lama dan melelahkan.

Setelah data-data tersebut terintegrasi, maka dalam peta digital akan tampil titik-titik rumah yang jika salah satu titik tersebut diklik, maka akan tampil nomor ID rumah dan foto rumah. Tidak ada deskripsi lebih lanjut mengenai kondisi rumah dan orang-orang yang tinggal di rumah tersebut beserta data sosial lainnya, karena memang belum dilakukan penggalian data sosial untuk memberi deskripsi mengenai isi rumah. 
Tahap selanjutnya adalah penggalian data sosial dengan mengisi formulir "Pemetaan Potensi Rumah Tangga Pedesaan". ${ }^{15}$ Sebelum terjun ke lapangan, seluruh tim pendataan dibekali pengetahuan teknis pengisian formulir, juga untuk menyamakan diksi (pilihan kata) dalam pengisian, sebab kalau diksi tidak sama, akan muncul kesulitan keterbacaan pada saat pengolahan data ke microsoft excel. Meski demikian, ternyata, hasilnya masih banyak ketidakseragaman diksi yang menyulitkan tim pengolah data dalam menganalisis data. Misalnya, "genteng" ditulis "genting". Begitu pula menyangkut satuan luas, penghitungan tidak seragam, termasuk juga penghitungan belanja rumah tangga. Penginputan dan pengolahan data karenanya butuh waktu lama dan njelimet.

Saat turun lapangan, banyak kendala yang dihadapi. Saat satu tim memasuki rumah untuk melakukan wawancara, sering kepala keluarga sedang tidak ada di rumah. Begitu pula saat pengisian nomor KK dan NIK anggota keluarga, banyak ditemukan foto copy KK yang angka dan hurufnya sulit dibaca sehingga menyulitkan pendata mengisi NIK. Juga beberapa warga belum memiliki kartu keluarga. Selain itu, menyangkut penghitungan belanja rumah tangga, tidak semua jawaban yang diberikan valid seratus persen, karena penghitungan dilakukan secara cepat dan tidak terlalu rinci. Kadang ada juga kecenderungan membesarkan pengeluaran dan mengecillkan pendapatan. Konon, ini lumrah di desa-desa ketika berlangsung survei ekonomi oleh pemerintah. Dengan membesarkan pengeluaran dan mengecilkan pemasukan, maka mereka akan bisa dikategorikan sebagai keluarga yang kurang mampu sehingga kesempatan memperoleh bantuan dari pemerintah cukup lebar.

Pendataan sosial/survei rumah tangga juga sangat berjalan lamban dan tumpang tindih. Tiga tim pendataan tidak berjalan secara serentak dan berkesinambungan. Masing-masing tim terdiri dari dua orang: pewawancara dan pencatat. Sering, salah satu anggota dari masing-masing tim tidak bisa melaksanaan pendataan karena ada pekerjaan yang lebih bernilai ekonomis. Itu tidak bisa dicegah karena menyangkut sumber penghidupan keluarga. Sebagian besar tim pemetaan tidak memiliki pekerjaan tetap alias serabutan, lebih sering bekerja sebagai buruh tani. Pendataan menjadi sangat lamban -

\footnotetext{
${ }^{15}$ Contoh formulir pendataan terlampir.
} 
berbulan-bulan- dan tidak fokus, koordinasi lemah, formulir-formulir yang sudah terisi tidak terarsip rapi dan terintegrasi. Ada juga formulir yang sudah terisi malah hilang, sehingga harus dilakukan pendataan ulang. Kendala lain, karena tidak sedikit kepala keluarga yang bekerja ke luar kota atau bahkan ke luar negeri, proses pendataan menjadi sulit mengingat anggota keluarga yang tinggal di rumah enggan atau tidak menguasai seluk-beluk urusan rumah tangga dan lain-lain sesuai dengan pertanyaan-pertanyaan yang diajukan.

Akhirnya, setelah pendataan sosial/survei rumah tangga secara keseluruhan selesai, kegiatan selanjutnya adalah penginputan data sosial ke microsoft excel untuk selanjutnya diintegrasikan ke QGIS. Karena ternyata ada ketidakseragaman diksi atau penulisan angka atau penghitungan -luas lahan, hasil produksi pertanian maupun perkebunan, belanja rumah tangga- dalam pengisian data sosial, ketika mau diolah, banyak data yang tak terbaca sehingga harus diseragamkan terlebih dulu. Karena itu, semua tim pendataan harus duduk bersama saling mengoreksi data yang ada. Kegiatan ini tentu saja tak mudah, perdebatan seringkali muncul meski akhirnya semua tim bisa mencapai kesepakatan.

Setelah penginputan data sosial selesai, kemudian diintegrasikan dengan data spasial di QGIS sehingga akan muncul suatu peta digital dan titiktitik permukiman, yang jika di klik salah satu titik tersebut akan muncul informasi yang berisi foto rumah, kepala keluarga, dan data-data sosial lainnya sebagaimana disebutkan di atas. Maka terciptalah satu sistem data base menyangkut peta spasial dan sosial masyarakat Dusun Barat Sawah Desa Rowosari Kecamatan Sumberjambe Kabupaten Jember. Seluruh data spasial dan sosial dalam sistem ini akan mudah diperbarui, sehingga informasi yang tersedia akan selalu up to date. Dengan demikian, sistem data base ini bisa menjadi dasar bagi masyarakat dusun dan perangkat dusun untuk membuat rencana program dusun yang bisa disampaikan pula dalam kegiatan musrenbang desa. Sistem data ini akan dikelola oleh seorang admin yang disepakati oleh masyarakat dalam hal penunjukannya. Data yang terdapat dalam sistem data ini harus bersifat satu pintu untuk mengaksesnya, dan karena itu harus dibuat standar operasional prosedur untuk tata kelolanya. Hal ini dilakukan untuk menghindari pemanfaatan data untuk kepentingan yang 
tidak sejalan dengan kepentingan masyarakat Dusun Barat Sawah, atau penyalahgunaan data.

Selanjutnya, tim pemetaan secara bersama-sama membuat peta Desa Rowosari dalam bentuk tiga dimensi. Peta ini tidak terinci, hanya memuat batas wilayah, tata guna lahan, kontur per mdpl, jalan desa, aliran irigasi, yang berfungsi memberikan gambaran miniatur desa. Melalui peta tiga dimensi ini orang dapat memperoleh gambaran secara global kondisi spasial Desa Rowosari. Setelah semuanya selesai: spasial dan sosial sekaligus pembuatan peta tiga dimensi, launching hasil pemetaan dilakukan di masjid di Dusun Barat Sawah dengan mengundang seluruh warga Dusun Barat Sawah dan perwakilan pemerintah Desa Rowosari. Kegiatan ini sekaligus dalam rangka mempertanggungjawabkan seluruh rangkaian kegiatan pemetaan dan sekaligus sarana koreksi data secara bersama-sama. Warga Dusun Barat Sawah merespon baik hasil pemetaan ini, demikian pula perangkat desa, sangat antusias sekali dan menganggap sistem informasi data ini dapat menjawab problem carut-marutnya data di tingkat desa yang berdampak pula di tingkatan di atasnya (kacamatan, kabupaten dan nasional). Pihak perangkat karenanya berjanji akan menindaklanjuti kegiatan ini di tingkat desa. Namun, kenyataannya, situasi politik tidak menguntungkan. Ekskalasi konflik semakin meningkat. Pihak-pihak lawan politik kepala desa yang sedang menjabat, Wasi, terus mengupayakan pergantian kepala desa mengingat kondisi Wasi dianggap tidak memungkinkan dalam menjalankan roda pemerintahan desa. Walhasil, kegiatan pemetaan di tingkat desa belum bisa dilaksanakan.

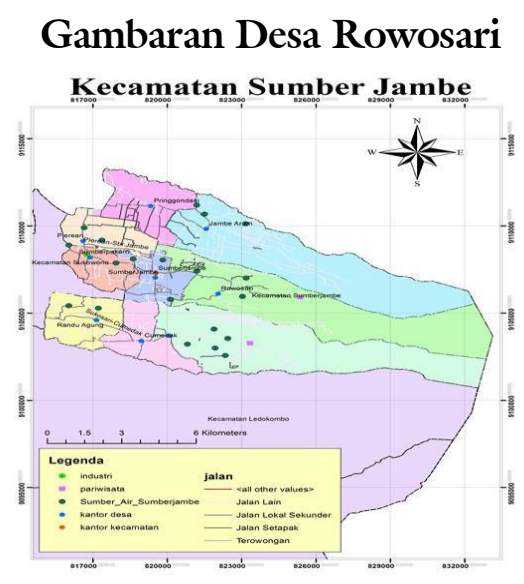


Secara administratif, desa Rowosari terletak di wilayah kecamatan Sumberjambe yang berbatasan dengan kecamatan Sukowono di sebelah barat, Ledokombo di sebelah selatan, kabupaten Banyuwangi di sebelah timur dan kabupaten Bondowoso di sebelah utara. Terdapat sembilan desa di wilayah kecamatan Sumberjambe: Randuagung, Cumedak, Gunungmalang, Rowosari, Sumberjambe, Sumberpakem, Plerean, Pringgodani, dan Jambearum.

Rowosari, menurut ilmu bumi, berada pada $4^{\circ} 21^{\prime}-3^{\circ} 31^{\prime}$ lintang selatan dan $140^{\circ} 10^{\prime}-115^{\circ} 40^{\prime}$ bujur timur. Secara topografis, ketinggian desa berupa dataran sedang: 550 meter di atas permukaan laut. Berdasarkan data BPS tahun 2004, curah hujan mencapai 2.400 milimeter, tertinggi 405,04 milimeter pada bulan Desember. Dari ibukota kabupaten ke desa berjarak 39, 3 kilometer dengan waktu tempuh satu setengah hingga dua jam arah timur laut. Tak ada alat transportasi umum ke desa ini. Di sisi utara, desa ini berbatasan dengan desa Jambearum; di sisi barat berbatasan dengan desa Sumberjambe; di sisi selatan berbatasan selatan berbatasan dengan desa Gunungmalang, dan di sisi timur berbatasan dengan kawasan hutan di kaki gunung Raung. Desa ini terbagi ke dalam 6 dusun dengan 12 RW dan 29 RT: Gardu Utara, Gardu Tengah, Gardu Timur, Pring Paddu, Lumbung dan Barat Sawah.

Mengenai kependudukan, berdasarkan Statistik Daerah Kecamatan Sumberjambe Tahun 2015, ${ }^{16}$ Rowosari terdiri dari 2391 kepala keluarga. Dengan luas wilayah desa $6,53 \mathrm{~km}^{2}$ dan jumlah penduduk, maka tingkat kepadatan penduduk di Rowosari 757,48 jiwa $/ \mathrm{km}^{2}$. Mengacu pada Undang-undang Nomor: 56/PRP/1960, maka tingkat kepadatan penduduk di Rowosari termasuk dalam kategori sangat padat (lebih dari 401 jiwa $/ \mathrm{km}^{2}$ ).

Sejarah desa bermula dari kedatangan Bujuk ${ }^{17}$ Marliya yang berasal dari Lamparan, Sampang, Madura ke kawasan hutan dan rawa-rawa di bawah kaki gunung Raung, yang kini menjadi bagian dari wilayah desa Rowosari, sekitar pertengahan abad 19. Sebelum mbabat alas, Bujuk Marliya melakukan ritual puasa selama empat puluh hari. Bujuk Marliya dikenal sebagai

\footnotetext{
${ }^{16}$ Statistik Daerah Kecamatan Sumberjambe Tahun 2015, No. Publikasi: 35095.1560, Katalog BPS: 1101002.3509260. Publikasi PDF dengan alamat http://jemberkab.bps.go.id.
} 
orang sakti, bahkan macan pun takut padanya. Istrinya, kono, adalah seorang bidadari. Makamnya terletak di pingir hutan pinus di dusun Barat Sawah yang berbatasan dengan desa Gunungmalang.

Bujuk Marliya memiliki dua orang istri dan sepuluh anak, yaitu Bujuk Landep, Bujuk Jisin, Bujuk Riya, Bujuk Sudin, Bujuk Dirat, Bujuk Arliman, Bujuk Purusa, Bujuk Manukdin, dan Bujuk Karidin. Catatan silsilah Bujuk Marliya dan keturunannya tersimpan di rumah Kyai Burhan, salah satu tokoh masyarakat di Karangtengah. Kyai Burhan sendiri merupakan keturunan ketujuh, yang menurut garis silsilah merupakan keturunan paling tinggi yang masih hidup. Catatan mengenai silsilah tersebut ditulis dengan huruf Arab dalam bahasa Madura (pegon). Anak cucu Bujuk Marliya kini berjumlah ribuan dan tersebar di beberapa desa di kawasan kecamatan Sumberjambe, meskipun sebagian besar tinggal di Desa Rowosari. Tiap tahun, pada bulan Suro (Muharram), anak cucu Bujuk Marliya berkumpul di area makam membaca tahlil bersama dan pembacaan riwayat singkat sang Bujuk, setelah sehari sebelumnya diadakan semaan al-Qur'an. Semua warga yang datang membawa berkat untuk saling ditukarkan dengan warga yang lain.

Nama Rowosari didasarkan pada banyaknya sumber mata air yang menyebabkan banyak rawa di daerah ini. Mengenai sejarah pemerintahan desa, Rowosari pertama kali dipimpin oleh Arja’u (1949-1959), Singojoyo (1959-1966), Wono Tirto (1966-1970), Usdiman ( 1970-1977), Muh. Talha (1977-1993), Supardi (1993-1997), Jamilah Supardi (1997-2013) dan Wasi (2013-2019).

Di blog resmi desa, tercantum visi dan misi desa Rowosari. ${ }^{18}$ Visi desa ini adalah "Terwujudnya Desa Rowosari yang Rukun dan Makmur serta Terdepan dalam Bidang Pertanian”. Dijelaskan dibawahnya bahwa dengan visi ini akan terwujud masyarakat Rowosari yang maju dalam bidang pertanian sehingga bisa mengantarkan kehidupan yang rukun dan makmur. Di samping itu, diharapkan juga akan terjadi inovasi pembangunan desa dalam berbagai bidang utamanya pertanian, perkebunan, peternakan, pertukangan, dan kebudayaan yang ditopang oleh nilai-nilai keagamaan.

Untuk misi Desa Rowosari, ada sepuluh item. Pertama, meujudkan dan mengembangkan kegiatan keagamaan untuk menambah keimanan dan

\footnotetext{
${ }^{18}$ Desarowosarisumberjambe.blogspot.com, diakses tanggal 31 Januari 2019.
} 
ketakwaan kepada Tuhan Yang Maha Esa. Kedua, Mewujudkan dan mendorong terjadinya usaha-usaha kerukunan antara dan intern warga masyarakat yang disebabkan karena adanya perbedaan agama, keyakinan, organisasi, dan lainnya dalam suasana yang saling menghargai dan menghormati. Ketiga, membangun dan meningkatkan hasil pertanian dengan jalan penataan pengairan, perbaikan jalan sawah/jalan usaha tani, pemupukan dan pola tanam yang lebih baik. Keempat, menata pemerintahan Desa Rowosari yang kompak dan bertanggung jawab dalam mengemban amanat masyarakat. Kelima, meningkatkan pelayanan masyarakat secara terpadu dan seirus. Keenam, mencari dan menambah debit air untuk mencukupi kebutuhan pertanian. Ketujuh, menumbuhkembangkan elompok tani dan gabungan kelompok tani serta bekerja sama dengan HIPPA guna memfasilitasi kebutuhan petani. Kedelapan, menumbuhkembangkan usaha kecil dan menengah. Kesembilan, bekerjasama dengan dinas kehutanan dan perkebunan dalam melestarikan lingkungan hidup. Kesepuluh, membangun dan mendorong majunya bidang pendidikan baik formal maupun informal yang mudah diakses dan dinikmati seluruh warga masyarakat tanpa terkecuali yang mampu menghasilkan insan intelektual, inovatif dan enterpreneur (wirausahawan).

\section{Gambaran Dusun Barat Sawah}

Lahan menjadi faktor produksi terpenting dalam menopang perekonomian masyarakat Rowosari sebagai daerah yang berekologi pertanian. Namun, ironisnya, lahan-lahan di Rowosari hanya dimiliki oleh segelintir saja dari seluruh masyarakat Rowosari. Bahkan, sekian persen lahan dimiliki oleh orang-orang dari luar Rowosari. Dalam kepemilikan lahan tersebut, Yuk -sebutan untuk etnis Tionghoa- menempati posisi dominan. Sentimen etnis, khususnya terhadap Yuk-Yuk penguasa lahan, menjadi gejala umum, walau tidak tampak di permukaan. Dalam obrolan tidak resmi, keresahan terhadap ekspansi penguasaan lahan oleh "yuk-yuk" sering mengemuka.

Namun, realitanya, pertanian di Rowosari agaknya tidak bisa lagi menjadi tumpuan hidup bagi sebagian masyarakatnya. Kepemilikan lahan pertanian kian merosot, bahkan sebagian bisa dikatakan tidak lagi memiliki lahan. Mereka kini justru menjadi penumpang di desanya sendiri. Dari satu dusun 
sampel, yakni Dusun Barat Sawah, dusun di mana Bujuk Marliya dimakamkan, diperoleh data sebagai berikut: dari 281 kepala keluarga, 221 kepala keluaraga (78 persen) masyarakat Barat sawah bekerja di sektor pertanian mencakup petani dan buruh tani. Artinya, pertanian menjadi sektor utama ekonomi masyarakat Barat Sawah.

Namun, dari jumlah 221 kepala keluarga yang menggantungkan hidupnya di sektor pertanian tersebut, 156 kepala keluarga (70 persen) menjadi buruh tani. Itu artinya lebih dari separuh (2/3) jumlah warga Dusun Barat Sawah yang mengaku sebagai keturunan Bujuk Marliya hidup dari tanah pertanian bukan miliknya. Tapi tak semuanya dari $156 \mathrm{KK}$ tersebut tidak memiliki tanah sawah sama sekali. Dari $65 \mathrm{KK}$ yang mengaku sebagai petani, diperoleh data $15 \mathrm{KK}$ yang memiliki tanah sawah di atas 1 hekar dengan rincian: $4 \mathrm{KK}$ memiliki sawah dengan luas 1 hektar, $1 \mathrm{KK}$ seluas 1,5 hektar, 2 KK seluas 2 KK hektar, 2 KK seluas 3 hektar, dan 4 KK memiliki lebih dari 5 hektar. Selebihnya $(50 \mathrm{KK})$ memiliki tanah sawah di bawah 1 hektar. Ada 81 lebih KK yang memiliki tanah kurang dari 0,5 hektar persegi. Dari $81 \mathrm{KK}$ ini, $16 \mathrm{KK}$ bisa jadi termasuk mereka yang mengaku sebagai buruh tani yang berjumlah total $156 \mathrm{KK}$ sebagaimana telah disebutkan di atas.

Ketimpangan penguasaan lahan pertanian tampak cukup lebar. Penguasaan lahan pertanian terkonsentrasi hanya ke segelintir orang. Pelapisan sosial, dengan demikian, bisa dikelompokkan menjadi petani kaya (mereka yang mempunyai lahan lebih dari 2 hektar), petani sedang (antara 1-2 hektar) dan miskin (di bawah 1 hektar). Sebagian besar masyarakat Barat Sawah yang bekerja di sektor pertanian berada di lapisan petani miskin (yang juga mencakup buruh tani). Mereka bekerja ke lapisan di atasnya, terutama pada petani kaya. Dengan rata-rata penghasilan per rumah tangga antara 400 hingga 500 ribu perbulan, jelas, penghasilan ini jauh dari mencukupi untuk memenuhi kebutuhan hidup sehari-hari. Kemiskinan, dengan demikian, kuat membayangi kehidupan masyarakat Barat Sawah.

Situasi kemiskinan tersebut berkelindan dengan keadaan lingkungan dan sosial yang tergambar dalam temuan data bahwa dari 281 kepala keluarga, hanya 36 (12,8 \%) saja yang memiliki jamban, selebihnya memanfaatkan sungai. Sekitar 60 persen rumah berdinding bambu atau papan 
kayu. Dari keseluruhan kepala rumah tangga, hanya 1 kepala keluarga lulus Diploma IV, 12 lulus SMA, 20 lulus SMP, selebihnya terbagi antara lulus SD, tidak tamat SD, dan tidak sekolah yang jumlahnya mencapai 89 persen dari seluruh jumlah kepala keluarga. Artinya, lingkungan yang tidak sehat dan rendahnya kualitas sumberdaya manusia menjadi beban berat bagi dinamika sosial di Barat Sawah.

\section{Lahan Yang Semakin Hilang}

Jelas bahwa ada perbedaan luas kepemilikan lahan di Dusun Barat Sawah. Bahkan ada kecenderungan pemusatan lahan pada lapisan atas masyarakat. Jumlah pemilik lahan sempit semakin besar bahkan ada kecenderungan banyak petani berlahan sempit akan kehilangan lahannya, artinya tidak memiliki lahan sama sekali atau tunakisma. Bagaimana ini terjadi?

Ada tiga cara proses pengalihan dan pemsuatan lahan di kalangan sedikit orang di Barat Sawah: yakni jual beli, sewa lahan, dan gadai lahan. Biasanya, untuk kebutuhan menikahkan anak, sunatan, atau selamatan lainnya, kebutuhan akan uang dengan jumlah besar dirasa mendesak. Hasil usaha pertanian bagi sebagian masyarakat Dusun Barat Sawah yang hanya cukup untuk kebutuhan hidup sehari-hari (ekonomi subsisten) memaksa mereka harus mencari dana cash untuk menyelenggarakan pernikahan, sunatan, atau selamatan lain. Karena tidak ada benda berharga yang bisa dijual atau digadaikan, maka lahan sawah menjadi pilihan satu-satunya untuk disewakan, digadaikan atau dijual. Sistem sewa sendiri cenderung dihindari oleh pihak yang meminjamkan dana, karena usaha tani sendiri dianggap berisiko dan kalau toh untung tidak seberapa. Dengan alasan itu, pihak yang meminjamkan menawarkan sistam gadai. Artinya, bagi yang meminjamkan dana tidak ada risiko yang harus dihadapi, sementara uang nantinya kembali utuh. Dia bisa memanfaatkan lahan gadai untuk usaha tani seolah-olah lahan tersebut miliknya, tanpa biaya sewa sepeserpun yang dikeluarkannya. Bagi pihak peminjam dana, karena kebutuhan yang mendesak dan tidak ada pilihan lain, maka tawaran pihak yang meminjamkan terpaksa dia terima. Akibatnya, selanjutnya, pihak peminjam kehilangan sumber penghasilan utamanya. Dia kini murni menjadi buruh tani di sawah miliknya. Karena pekerjaaan sebagai buruh tani bersifat temporal (bukan pekerjaan harian) dan tidak mencu- 
kupi untuk menopang kebutuhan hidup sehari-hari, dia akan memilih pergi ke luar desa mencari pekerjaan di kota atau di luar daerah, menjadi buruh migran. Biasanya mereka memilih bekerja di Bali atau ke luar Malaysia. Karena tidak memiliki keterampilan selain pertanian, di Bali mereka kebanyakan memilih bekerja sebagai kuli bangunan.

Sayangnya, umumnya, tanah yang digadaikan jarang kembali lagi ke tangan pemiliknya. Lahan-lahan itu secara perlahan hilang bersamaan dengan semakin besarnya uang tambahan yang diminta orang yang menggadaikan kepada yang memberi peminjam uang. Itu terutama disebabkan di Barat Barat Sawah, atau Desa Rowosari pada umumnya, hampir setiap hari besar Islam masyarakat merayakannya dengan mengadakan kenduri atau slametan. Di bulan Muharram atau Suro, pada tanggal 10, mereka mengadakan santunan anak yatim yang diisi pula dengan berbagai kegiatan lain: pawai keliling dan pengajian. Untuk penyelenggaraannya, masyarakat iuran. Jika bulan maulid, selamatan maulidan hampir tiap hari ada. Setiap dua atau tiga (bisa pula lebih) keluarga yang masih berkerabat dekat iuran untuk menyelenggarakan selamatan maulid dengan mengundang tetangga dan kerabat dekat maupun yang jauh lintas desa. Kebutuhan untuk kegiatan ini cukup besar, karena selain menyajikan nasi piringan dan kue untuk di makan saat acara, juga ada yang dibawa pulang berupa berkatan yang berisi nasi, lauk-pauk, dan kue-kue. Kebutuhan uang kontan lain adalah untuk persiapan menjelang lebaran: perbaikan rumah, kendaraan, pakaian baru, jajanan dan uang untuk kebutuhan transportasi dalam rangka berkunjung ke kerabat. Untuk kebutuhan itu, dan kebutuhan-kebutuhan lainnya, biasanya orang yang menggadaikan lahannya, biasanya meminta tambahan pinjaman dana kepada si pemberi pinjaman. Jika jumlah dana yang dipinjam semakin membengkak, semakin sulit bagi si peminjam untuk bisa mengembalikan uang pinjaman. Nah, ketika si pemberi pinjaman kemudian ingin menarik lagi pinjamannya (biasanya hanya strategi untuk menggertak), si peminjam atau pemilik lahan akan dengan terpaksa menawarkan lahannya untuk dibeli si pemberi pinjaman. Di sinilah titik peralihan kepemilikan lahan. Dan, ironisnya, harga jual lahan bisanya di bawah harga pada umumnya. Itu dimungkinkan karena si peminjam memiliki ketergantungan yang kuat kepada yang memberi pinjaman. Dan, tak sedikit tanah yang sudah berpindah tan- 
gan itu dijual lagi dengan harga jual yang lebih tinggi kepada Yuk-Yuk pasar Sukowono yang memang terkenal kaya-kaya karena usaha perdagangannya.

Bisa ditebak, maka akan banyak lahan-lahan pertanian yang berpindah tangan dari petani-petani kecil ke petani besar atau orang-orang di luar desa Rowosari, terutama orang-orang etnis Tionghoa pemilik toko-toko di pasar Sukowono (pasar yang terbesar di kawasan itu) yang kelebihan modalnya diinvestasikan dalam bentuk tanah pertanian. Tak heran, muncul sentimen masyarakat Barat Sawah terhadap Yuk-Yuk (sebutan untuk etnis Tionghoa) karena mereka banyak menguasai lahan pertanian di desa-desa setempat. Seringkali, saya ditawari untuk membeli lahan persawahan di Barat Sawah atau Rowosari agar tidak terbeli oleh Yuk-Yuk karena jika yang membeli Yuk, maka orang-orang Barat Sawah atau Rowosari sendiri tidak dipekerjakan (sebagai buruh tani) di lahan pertaniannya. Entah apa alasan Yuk-Yuk itu tidak memperkejakan orang-orang setempat untuk merawat usaha pertaniannya.

Sistem gadai, dari praktik yang berlaku di Barat Sawah, cenderung merugikan pihak yang menggadaikan dan, sebaliknya, menguntungkan pihak yang meminjamkan dana. Si pemberi pinjaman dana bisa mengelola lahan sawah gadai tersebut untuk usaha komersil, sementara dana yang dipinjamkan kepada pihak yang menggadaikan umumnya untuk kepentingan ritual yang non komersil. Karena dana pinjaman tidak diputar untuk kegiatan komersil, dan cenderung sekali pakai habis, maka kesulitan ganda menjerat pihak yang menggadaikan lahan, di satu sisi dia kehilangan salah satu sumber pendapatan dari usaha tani sehinga harus mencari pekerjaan lain yang di luar keterampilannya sebagai petani, di sisi lain dia harus mengumpulkan dana untuk bisa menebus lahan yang digadaikan. Kenyataannya, pekerjaan di luar pertanian tidak memberikan penghasilan yang mencukupi, bahkan untuk kebutuhan hidup sehari-hari, alih-alih menabung dari sisa kebutuhan harian. Dengan demikian, proses kehilangan lahan bagi petani-petani berlahan sempit akan terus-menerus berlangsung. Konsentrasi kepemilikan lahan ke segelintir orang baik di Barat Sawah sendiri maupun orang-orang di luar Barat Sawah bahkan luar desa akan semakin menguat. Akibatnya, petanipetani berlahan sempit di Barat Sawah seolah menjadi "gelandangan di kampung sendiri”. 
Melalui sistem gadai lahan pertanian inilah proses penghilangan lahan dari para petani berlangsung. Sementara, di sisi lain, para petani dengan lahan sempit tidak bisa tidak seringkali terbentur dengan kebutuhan akan dana cash dengan jumlah besar untuk kegiatan perkawinan, perayaan hari besar Islam, selamatan, biaya pendidikan dan lain-lain. Mereka tak memiliki akses terhadap modal, atau pinjaman dana lunak yang tidak menjerat, sehingga terpaksa mereka berhubungan dengan para pemberi pinjaman dana dengan cara menggadaikan lahan pertaniannya. Tidak hanya lahan pertanian saja yang digadaikan, bahkan pohon-pohon durian juga tak luput digadaikan. Selama masa gadai berlaku, selama itu pula pihak pemberi pinjaman memetik buah durian dan menjualnya sementara pihak yang menggadaikan (pemilik pohon durian) tidak berhak menikmatinya.

\section{Bertahan atau Keluar Desa?}

Dari uraian di atas, terlihat adanya diferensiasi lapisan masyarakat di Barat Sawah yang menjadikan pertanian sebagai tumpuan utama kehidupan mereka. Penyebab utama diferensiasi itu adalah terjadinya pemusatan kepemilikan tanah pada lapisan atas dari masyarakat Barat Sawah. Dari seluruh tanah pertanian di Barat Sawah, hampirseparuhnya dikuasai oleh hanya segelintir orang, sementara sisanya hanya memiliki sebidang tanah kecil, bahkan sebagiannya sama sekali tidak memiliki tanah pertanian.

Di antara lapisan petani kaya (pemilik tanah besar) dan golongan tunakisma (mereka yang tak mempunyai tanah atau memiliki tanah yang sangat sempit) terbentuk hubungan kelas yang berupa sistem penyakapan tanah dan perburuhan. Hubungan ini bersifat vertikal. Bahkan, oleh karena kuatnya tingkat ketergantungan golongan tunakisma kepada pemilik tanah, hubungan tersebut cenderung bersifat patron-klien. Hal ini membuat golongan tunakisma sulit untuk meningkatkan kapasitas dan kehormatan mereka. Parahnya, kesempatan kerja di luar sektor pertanian yang tersedia bagi masyarakat sangat terbatas.

Bayi-bayi dilahirkan. Manusia-manusia baru terus bermunculan. Mereka pun berebut ruang ekonomi. Tanah pertanian tak bertambah, malah semakin berkurang, bahkan banyak petani-petani kecil yang kehilangan lahan pertanian. Hidup dari ekonomi pertanian sungguh tidak menjanjikan bagi 
para petani lahan sempit dan buruh tani. Hasil panen dikurangi biaya produksi tak memberikan keuntungan yang cukup untuk menopang kehidupan sehari-hari. Hanya petani dengan luas lahan di atas 2-3 hektar yang bisa bertahan dari usaha tani. Bagi petani kecil, mereka menghadapi dilema: bertahan di desa dengan mengandalkan usaha tani dengan lahan sempit ataukah bekerja di luar sektor pertanian? Rumitnya, di desa sendiri tidak menyediakan lapangan kerja di luar sektor pertanian, ditambah lagi tidak adanya keterampilan yang mereka miliki untuk bekerja di luar sektor pertanian.

Apakah mereka akan terpaksa meninggalkan desa? Pertanyaan yang tak mudah dijawab tersebut menjadi hantu bagi dinamika kehidupan desa. Namun, agaknya, pergi ke luar desa adalah sebuah pilihan yang "rasional". Dan, memang, di Barat Sawah, ada kecenderungan terjadi perpindahan tenaga mencari pekerjaan baru di luar desa. Biasanya mereka memilih menjadi buruh bangunan di kota atau daerah-daerah yang jauh dari desa. Bali menjadi tujuan favorit anak-anak muda. Sementara di kalangan orang dewasa, terutama kaum perempuan, menjadi TKI/TKW merupakan pilihan utama, kebanyakan ke Malaysia. Timbul masalah baru, untuk lewat jalur resmi, mereka terkendala biaya administrasi dan prosedur yang dirasa memberatkan. Maka, sebagian dari mereka berangkat melalui jalur tak resmi. Risiko menjadi TKI/TKW gelap sangat besar, tak ada pihak penjamin keamanan dan keselamatan mereka ketika hidup di negeri orang.

Hasan (Pak Arif), warga kampung Karang Tengah Barat Sawah adalah contoh TKI yang bekerja di Malaysia melalui jalur tak resmi. Dia tak memiliki lahan pertanian, dan selama ini bekerja sebagai buruh tani dan serabutan. Hasan memiliki seorang istri dan satu anak yang masih TK. Sebagai pasangan muda, Hasan belum memiliki rumah sendiri dan menumpang di rumah mertuanya. Keinginan untuk memiliki rumah sendiri begitu kuat. Apalagi mendengar salah seorang kerabatnya mau menjual bangunan rumah (terbuat dari papan kayu lengkap dengan gentingnya) untuk dibangun rumah baru berdinding tembok. Bangunan kerangka rumah itu nantinya akan dipindahkan di lahan kosong miliknya yang berukuran 6x12 meter. Karena bekerja sebagai buruh tani tidak bisa diandalkan untuk menopang hidup. Rumah itu ditawarkan seharga 3 juta. Untuk memperoleh uang sebesar itu, tidak mungkin didapatkan dengan bekerja keras sekalipun jika di Barat Sa- 
wah. Karena itu, Hasan memutuskan ikut ajakan seorang kerabatnya dari desa sebelah yang sudah terlebih dulu bekerja di Malaysia. Sebagaimana kerabatnya, dia berangkat secara tak resmi. Di tempatnya bekerja, setiap saat Hasan dicemaskan oleh ancaman dijebloskan ke penjara oleh polisi Diraja Malaysia jika ketahuan tidak memiliki dokumen resmi ketenagakerjaan.

Satu dua bulan Hasan bisa bernafas lega karena bisa bekerja tanpa diketahui oleh aparat Malaysia. Dia pun sempat dua kali mengirimkan hasil jerih payahnya ke istrinya untuk digunakan memenuhi kebutuhan harian dan membeli rumah. Gaji bulan ketiga digunakan untuk membeli sepeda motor bekas. Menjelang ramadhan, Hasan berencana pulang ke kampung halaman karena niatnya untuk membeli rumah dan sepeda motor sudah terpenuhi. Namun naas, malam menjelang keberangkatan pulang ke Indonesia, dia ditangkap oleh polisi Diraja Malaysia. Terpaksa Hasan menjalani hukuman selama dua bulan di penjara. Setelah keluar, dia dideportasi dan pulang tanpa membawa uang sepeserpun.

Kasus Hasan hanyalah satu dari banyak warga Barat Sawah yang bekerja ke luar desa. Hasan barangkali pengecualian di antara kecenderungan mereka yang bekerja ke luar dan "lupa" untuk kembali. Sejak awal, niat Hasan hanya satu: cari uang untuk membeli rumah Pak Sinta, tetangga sekaligus kerabatnya. Setelah keinginannya tercapai, Hasan memutuskan pulang dan tak ingin kembali lagi ke Malaysia walaupun di sana lebih mudah cari uang. Bagi Hasan, hidup berkumpul bersama anak dan istrinya lebih penting ketimbang mencari uang di luar dan terpisah dari keluarga. Kini, sepulang dari Malaysia, Hasan bekerja serabutan -buruh tani, pemikul kayu sengon, dan lain-lain yang bisa dikerjakannya.

Ketenangan hidup di desa sebenarnya membuat mereka yang bekerja ke luar desa begitu merindukan kembali pulang. Namun kesulitan ekonomi di desa membuat mereka terpaksa bertahan di perantauan. Hadis, tetangga rumah Hasan, misalnya, sering pulang dan pergi ke Bali. Jika merasa cukup banyak uang, Hadis pulang ke desa. Namun ketika persediaan uang mulai menipis, dia berangkat lagi ke Bali mencari kerja. Hola, yang juga masih bertetangga dengan Hasan dan Hadis, juga kerap pulang dan pergi ke Bali. Dia masih muda, belum berkeluarga. Namun untuk membeli rokok, gagdet dan bensin sepeda motornya -demi gaya hidup sebagaimana laiknya anak 
muda- memaksanya bekerja ke Bali untuk cari uang. Setelah dianggap cukup untuk hidup sebulan dua bulan di desa, dia pulang. Jika persediaan uang habis, dia berangkat lagi ke Bali cari uang. Di Bali, Hadis dan Hola bekerja sebagai kuli bangunan. Tidak ada keterampilan sebagai pekerja bangunan, sebenarnya. Mereka hanya mengandalkan tenaga kasar, sebagai pengangkut material bangunan atau pengaduk semen.

\section{Kemana Gerak Sosial Masyarakat Dusun Barat Sawah?}

Pola pertanian di Barat Sawah masih bergantung pada obat-obatan kimia. Bibit pertanian pun tidak dihasilkan sendiri, melainkan bergantung kepada perusahaan-perusahaan penyedia bibit. Sistem pemasaran hasil pertanian juga masih dikuasai oleh para tengkulak yang menikmati selisih yang cukup besar sebelum ke penguasa besar dan pasar. Biaya input pertanian tinggi dan sistem pemasaran yang tidak berpihak ke kaum tani menyebabkan ekonomi pertanian hanya menguntungkan petani besar dan para tengkulak. Sementara mereka yang bekerja mengolah sawah mendapat hanya sedikit yang tidak mencukupi untuk pemenuhan kebutuhan hidup seharihari. Di sinilah proses penghisapan terhadap kaum tani berlangsung, ketimpangan dan ketidakadilan ekonomi di desa terjadi. Di Rowosari sendiri, tidak ada lembaga ekonomi desa atau koperasi yang bisa melindungi permodalan, simpan pinjam, dan penyediaan kebutuhan pupuk dan obat-obatan untuk kaum tani.

Sistem pengetahuan petani sendiri cenderung monolitik, sangat tergantung pada resep pengolahan yang ditawarkan oleh toko-toko pertanian: bibit, pupuk dan obatnya. Petugas lapangan pertanian hanya memberi resep, tidak mendorong petani untuk kreatif menemukan pola pertanian sendiri. Petani tidak didorong untuk membuat pupuk dan obat-obatan pertanian organik dengan memanfaatkan apa yang ada di desa. Usaha pertanian di desa menjadi stagnan, malah cenderung menurun. Sistem pengetahuan masyarakat tentang usaha tani juga tidak berkembang. Inilah yang menyebabkan ekonomi pertanian tidak bisa diandalkan lagi oleh masyarakat desa.

Gerak sosial desa, agaknya, akan menjauh dari kehidupan pertanian. Ini akibat dari lahan-lahan pertanian yang semakin terkonsentrasi ke petanipetani kaya atau para pembeli lahan untuk kepentingan investasi. Semakin 
besarnya jumlah petani tak bertanah -tunakisma- membuat tenaga buruh tani dihargai murah. Ini menyebabkan banyak buruh tani yang selama ini menggantungkan ekonominya pada sektor pertanian beralih bekerja ke luar desa di luar sektor pertanian. Akibatnya, pertanian sebagai soko guru perekonomian desa menjadi goyah, yang pada gilirannya berdampak bagi bangunan sosial budaya masyarakat desa.

Dengan pendapatan rata-rata 500 ribu perbulan, taraf hidup umumnya masyarakat Barat Sawah, terutama di kampung Karangtengah, sangat rendah dan cenderung merosot. Kondisi fisik rumah, perabotan, pakaian dan makanan begitu sederhana. Untuk pakaian, misalnya, mereka hanya mampu membelinya sekali dalam setahun, saat lebaran. Lauk pauk, jika bukan tahu, adalah ikan tongkol yang diasinkan. Saya sering dijamu makan di beberapa rumah warga Karangtengah, ikan asin selalu menjadi lauk utama, dan rasa asinnya begitu kuat sehingga secuil kecil ikan asin cukup untuk lauk sekali makan.

Ekonomi sebagian besar masyarakat Barat Sawah yang selama ini menggantungkan hidupnya pada pertanian semakin merosot. Kemiskinan terus meningkat. Ini diakibatkan selain oleh konsentrasi lahan akibat banyaknya lahan-lahan pertanian sempit yang beralih kepemilikan akibat pinjam dana dengan sistem gadai ke petani kaya dan orang kaya di luar desa yang membeli lahan semata untuk aset, juga akibat dari stagnannya pola pertanian di Barat Sawah yang mengakibatkan hasil usaha tani tidak meningkat. Biaya input pertanian cukup tinggi dan sistem pengetahuan pertanian sangat tergantung pada perusahaan-perusahaan besar penyedia bibit dan pupuk pertanian. Di sisi lain, seiring dengan pertambahan penduduk, terjadi kelebihan tenaga kerja yang berdampak pada murahnya tenaga kerja di sektor pertanian. Mencari penghasilan di desa menjadi susah, sehingga muncul kecenderungan mencari kerja ke luar desa.

Di kalangan petani dengan lahan kecil yang bisa disebut kelas menengah Barat Sawah, yakni mereka yang memiliki lahan pertanian dan alat-alat produksi yang dapat mencukupi kebutuhan makanan yang pokok, terus berusaha bertahan agar tanah miliknya tidak sampai dijual atau tergadaikan. Mereka, selain bertani, mencari sambilan kerja lain untuk menopang kebutuhan belanja harian yang membutuhkan uang cash. Lama-lama kerja sam- 
bilan ke luar desa berubah menjadi pekerjaan pokok.

Urbanisasi, dan uang yang mengalir dari kota ke desa melalui orangorang urban ini kebanyakan tidak terkelola engan baik. Oleh keluarga di rumah, uang kiriman dari para pekerja migran ini cenderung habis untuk kebutuhan konsumtif: pakaian, kendaraan bermotor, alat-alat elektronik, telepon genggam dan gadget, dan mebeler. Uang kiriman tidak ditabaung atau digunakan sebagai modal usaha. Akibat hadirnya barang-barang kota, budaya konsumtif dan benda-benda pabrikan, berpengaruh terhadap gaya hidup orang-orang di desa. Dengan kendaraan bermotornya, anak-anak muda lebih suka jalan-jalan ke pusat-pusat keramaian untuk sekedar nongkrong atau cuci mata. Kehadiran gadget membuat uang habis untuk beli pulsa dan, parahnya, cenderung selalu mengganti gadget dengan keluaran terbaru. Anak-anak muda bahkan orang tua lebih gemar bermain gadget, nonton televisi dan lain-lain sehingga pola interkasi sosial di desa juga berubah. Saling bertandang dan kumpul-kumpul di rumah salah satu warga semakin langka. Ikatan sosial menjadi renggang.

Desa, kita tahu, memiliki bangunan sosial dan budaya yang kuat. Sifat gotong royong, kebersamaan dan sistem kekerabatan merupakan pengikat kuat kehidupan sosial masyarakat desa. Tradisi keagamaan maupun yang berbasis budaya lokal menjadi pembentuk kosmologi kehidupan desa. Ketahanan dan kedaulatan desa, dengan demikian, memperoleh fondasinya dari nilai-nilai tradisi dan budaya masyarakat desa. Namun, ketahanan ekonomi menjadi problem krusial masyarakat desa. Dan, ekonomi, agaknya memilik pengaruh kuat terhadap perubahan sosial budaya masyarakat, karena menyangkut bagaimana orang bertahan hidup. Pergeseran sistem ekonomi jelas akan menggeser nilai-nilai tradisi dan budaya.

\section{KESIMPULAN}

Melalui pemetaan sosial dan spasial diperoleh gambaran kemiskinan yang dihadapi oleh mayoritas masyarakat Barat Sawah.Kemiskinan ini terutama diakibatkan oleh berpindah tangannya lahan-lahan pertanian di kalangan masyarakat kelas menengah dan bawah Barat Sawah. Ketiadaan lahan, pekerjaaan sebagai buruh tani yang tidak setiap hari bekerja, ketidakseimbangan luas lahan pertanian yang menjadi lahan pekerjaaan dengan jumlah 
tenaga kerja yang semakin bertambah, membuat tak ada pilihan lain kecuali pergi daridesa.

Tak perlu dijelaskan panjang lebar bagaimana dampak kepergian orangorang desa ke luar desa. Lahan-lahan di desa menjadi incaran para pemilik modal untuk menginvestasikan modalnya dalam bentuk tanah. Maka, penguasaan lahan di desa semakin terkonsentrasi ke segelintir orang. Tatanan sosial desa menjadi timpang, sistem pertanian bisa saja bergeser dari pertanian yang berorientasi kepada produksi bahan makanan pokok (padi, jagung, kedelai) ke pertanian komersial seperti tebu, tembakau atau okrah dan edamami atau tanaman pertanian lain yang berorientasi ke pasar di kota oleh perusahaan-perusahaan komersil yang bergerak di bidang pertanian. Maka, pertanian akan memenuhi kebutuhan pasar dunia, bukan kebutuhan pangan masyarakat desa.Padahal untuk kebutuhan pangan masyarakat desa sendiri kurang.Dengan demikian, desa akan menghadapi ancaman ketahanan pangan.

Apa yang terjadi di desa, khususnya di Barat Sawah Desa Rowosari, sebenarnya bisa dipecahkan misalnya dengan melembagakan koperasi simpan-pinjam, pengolahan pertanian dengan menggunakan sistem pertanian organik, dan mengembangkan wisata desa dengan memanfaatkan potensi desa. Wisata alam: panorama pegunungan, air terjun, panorama persawahan dan sungai-sungai yang mengalir membelah desa dengan airnya yang jernih, menjadi daya tarik tersendiri untuk dikembangkan sebagai wisata desa. Peternakan dan perikanan juga sangat bisa dikembangkan mengingat melimpahnya air sungai dan sumber makanan hijau bagi hewan ternak.

Dana desa bisa digunakan untuk itu. Prioritas pembangunan desa seharusnya didasarkan pada analisis data hasil pemetaan partisipatif, bukan oleh segelintir elit pemerintahan desa. Prioritas program semestinya diarahkan pada membangun ketahanan pangan, penciptaan lapangan pekerjaan di desa menuju kedaulatan ekonomi desa.Selain itu, lahan-lahan dalam wilayah Perhutani atau hutan produksi yang mengelilingi Desa Rowosari sebenarnya bisa dikelolakan kepada masyarakat. Lahan tersebut sangat luas, mengitari Rowosari dan membentang memanjang dan meluas ke arah timur Rowosari, arah ke Gunung Raung. Namun, sayangnya, hak kelola lahan itu oleh Perhutani kebanyakan diberikan kepada orang-orang etnis Tionghoa yang 
mengelolanya untuk tanaman keras seperti sengon dan kopi. Orang-orang desa mau tidak mau hanya menjadi buruh upahan untuk merawat, memupuk dan memanen kopi atau sengon.Dengan medan yang cukup berat untuk mencapai lokasi, orang-orang desaakhirnya enggan mengelola lahan dengan upah sedikit dan pekerjaan yang tidak menentu. Mereka terpaksa mencari pekerjaan di luar desa.

Harus ada itikad baik dan keputusan politik oleh pemerintahan desa, misalnya dengan membuat peraturan desa mengenai larangan menjual lahan pertanian kepada orang di luar desa agar lahan-lahan di desa tidak beralih fungsi menjadi perumahan atau dijadikan aset untuk investasi yang tentu saja tidak memliki komitmen terhadap pengembangan pertanian di desa. Tak hanya itu, desa harus mengembangkan BUMDES sebagai usaha ekonomi dengan membuka lapangan pekerjaan untuk meningkatkan kesejahteraan masyarakat desa, khususnya yang tidak memiliki pekerjaan dan mereka yang tak memiliki lahan pertanian. Pengelolaan zakat, infak, shodaqoh dari orang-orang kaya di desa, jika dikelola dengan baik, dapat menjadi modal usaha atau membantu meringankan mereka yang benar-benar membutuhkan, sehingga mencegah orang-orang desa untuk hijrah ke kota. Karena, jelas, bahwa dengan hijrahnya orang-orang desa ke kota, ketika kembali ke desa, akan membawa kebudayaan kota yang belum tentu sesuai dengan nilai-nilai dan norma-norma yang berlaku di desa.

\section{DAFTAR PUSTAKA}

Clifford Geertz, Involusi Pertanian: Proses Perubahan ekologi Di Indonesia, terjemahan S. Supomo, (Jakarta: Bhratara Karya Aksara, 1976)

Hiroyoshi Kano, Pagelaran: Anatomi Sosial Ekonomi Pelapisan Masyarakat

Tani Di Sebuah Desa Jawa Timur, (Yogyakarta: Gadjah Mada University Press, 1990)

http://desarowosarisumberjambe.blogspot.co.id/p/blog-page.html

J.H. Boeke, Prakapitalisme di Asia, terj. D. Projosiswoyo, (Jakarta: Sinar Harapan, 1983)

Margo L. Lyon, Bases of Cinflict in Rural Java, Research Monograph Series

No. 3, (Center for South and Southeast Asia Studies, University of 
M. Ardiansyah, M. Salman Hamdani, Nukman Hakim, Khairuddin

California, 1970)

Sajogyo (peny.), Bunga Rampai Perekonomian Desa, Bogor: Yayasan Obor, 1982.

Sajogyo, "Pertanian, landasan tolak bagi pengembangan bangsa Indonesia", kata pengantar dalam buku terjemahan karya C. Geeertz, Involusi Pertanian, Proses Perubahan Ekologi di Indonesia, Jakarta, 1976.

Statistik Daerah Kecamatan Sumberjambe Tahun 2015, No. Publikasi: 35095.1560, Katalog BPS: 1101002.3509260. Publikasi PDF dengan alamat http://jemberkab.bps.go.id.

Tania Murray Li, The Will to Improve, Perencanaan, kekuasaan dan Pembangunan di Indonesia, terj. Hery Santoso dan Pujo Semedi, Tangerang Selatan: Marjin Kiri, 2012.

William L. Colier, Agricultural Evolution in Java: The Decline of Shared Poverty and Involution, (Bogor, n.d. c, 1977) 